\title{
Graft patency in diabetic patients and the discomfort of thought
}

\author{
Paul Kurlansky, MD
}

From the Division of Cardiac Surgery, Columbia University, New York, NY.

Received for publication Oct 8, 2017; revisions received Nov 14, 2017; accepted for publication Dec 6, 2017; available ahead of print March 30, 2018.

Address for reprints: Paul Kurlansky, MD, Black Building 210, 650 West 168th St, New York, NY 10032 (E-mail: Pk2245@cumc.columbia.edu).

J Thorac Cardiovasc Surg 2018;155:2316-21

$0022-5223 / \$ 36.00$

Copyright (C) 2018 by The American Association for Thoracic Surgery

https://doi.org/10.1016/j.jtcvs.2017.12.158

Editor's Note-The August 2017 publication in the Journal of the American College of Cardiology from Cleveland Clinic stunned the JTCVS Editors. We discussed the findings and wondered whether diabetics could really have as good graft patency as nondiabetics. We immediately recognized the sophisticated statistical analysis characteristic of our Statistical Editor. The JTCVS Editors unanimously agreed that we should publish a commentary on the JACC article. We were very pleased when our Associate Statistical Editor, Paul Kurlansky, agreed to prepare this Expert Opinion. We believe that all readers of our Journal will appreciate this outstanding editorial. The data from Cleveland Clinic are important, but just as compelling is the interpretation of these results provided by Dr Kurlansky. We hope that you enjoy this outstanding Feature Expert Opinion.

\section{Richard Weisel, MD Editor-in-Chief}

"Too often we...enjoy the comfort of opinion without the discomfort of thought."

—John F. Kennedy

Commencement Address at Yale University, June 11, 1962

The art of medicine might be described as the ability to make correct decisions on the basis of incomplete information. From a purely objective perspective, the "definitive" study on any given topic has never-nor ever will be-performed. The most comprehensive ones actually tend to raise more questions than they answer. However, occasionally we are confronted with the daunting challenge of ostensibly solid evidence that appears to contradict well founded (and perhaps even cherished) theoretical assumptions. It is just this puzzling circumstance that is presented by Raza and his colleagues from the Cleveland Clinic in their recent report on the "Influence of diabetes on long-term coronary

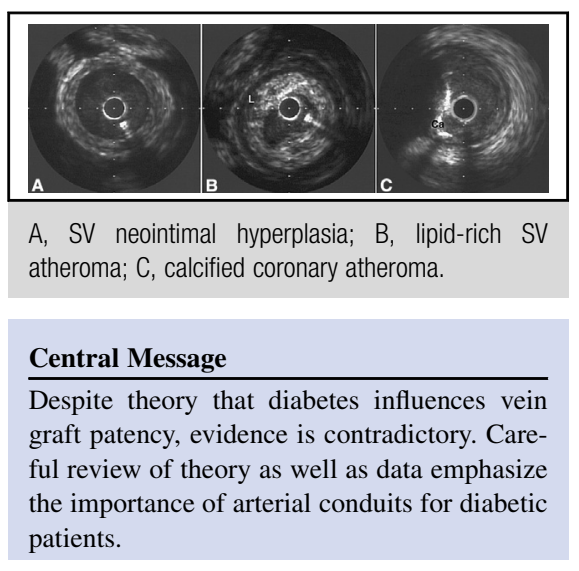

See Editorial Commentary page 2322. artery bypass graft patency." "Drawing on the incredibly rich data resource of 57,961 patients who underwent primary isolated coronary artery bypass grafting (CABG) between 1972 and 2011 at their institution, the authors were able to identify 11,519 patients, of whom 1372 were diabetic, who had interpretable coronary angiograms anywhere from $<1$ year up to 20 years after surgery, leaving them with a total of 28,460 individual bypass grafts (3796; 13.3\% in diabetic patients) for study. Following thorough and sophisticated statistical modeling, the authors reported that, regarding 7903 internal thoracic artery (ITA) grafts $(27.8 \%$ of the total number of grafts, of which 1132 or $14.3 \%$ were in diabetic patients), graft patency was stable over time with no difference between diabetic and nondiabetic patients (93\% vs $96 \%$ patency, respectively, at 20 years; $P=.30$ ). So far so good-encouraging, but not surprising. However, for saphenous vein (SV) grafts, patency declined over time: $78 \%, 70 \%, 57 \%$, and $42 \%$ in diabetic patients at $1,5,10$, and 20 years, and $82 \%$, $72 \%, 58 \%$, and $41 \%$ in nondiabetic patients, respectively $(P<.002$ early [up to 4 years], and $P=.60$ late [ $>4$ years]). Also not terribly surprising. But here is where things get interesting: after careful adjustment for potentially confounding risk factors, diabetes was actually associated with higher early ( $\leq 1$ year) ITA patency (odds ratio, $0.63 ; 95 \%$ confidence interval, $0.43-0.91 ; P=.013$ ) but similar late patency $(P=.80)$. However, early as well as late patency of SV grafts was similar between diabetic and nondiabetic patients ( $P=.90$ early, and .80 late). Leaving aside the potentially odd finding of increased early ITA patency which, at $97 \%$ versus $96 \%$ is of marginal clinical 
TABLE 1. Studies comparing diabetic and nondiabetic SV graft patency

\begin{tabular}{|c|c|c|c|c|c|c|c|c|c|c|}
\hline Reference & Year & Site & $\begin{array}{c}\text { Patients } \\
\text { studied, } \\
\text { n }\end{array}$ & Diabetic & $\begin{array}{c}\text { SV } \\
\text { grafts, } \\
\text { n }\end{array}$ & Diabetic & $\begin{array}{l}\text { Length of } \\
\text { follow-up }\end{array}$ & $\begin{array}{c}\text { Indication } \\
\text { for } \\
\text { angiography }\end{array}$ & $\begin{array}{c}\text { Study } \\
\text { patients with } \\
\text { angiographic } \\
\text { follow-up }\end{array}$ & Finding \\
\hline 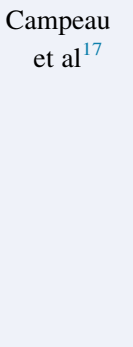 & 1984 & $\begin{array}{l}\text { Single } \\
\text { center }\end{array}$ & 82 & Unclear & 132 & & $\begin{array}{l}10 \text { years } \\
\text { compared } \\
\text { with } 1 \\
\text { year }\end{array}$ & $\begin{array}{l}\text { Mixed clinical/ } \\
\text { prospective } \\
\text { study }\end{array}$ & $55 \%$ & $\begin{array}{l}\text { In multivariable } \\
\text { analysis, diabetes } \\
\text { not associated with } \\
\text { disease } \\
\text { progression; } \\
\text { definition of } \\
\text { diabetes variable } \\
\text { between } 2 \text { time } \\
\text { points }\end{array}$ \\
\hline $\begin{array}{l}\text { Lytle } \\
\qquad \text { et al }^{18}\end{array}$ & 1985 & $\begin{array}{l}\text { Single } \\
\text { center }\end{array}$ & 501 & $18 \%$ & 786 & $18 \%$ & $\begin{array}{l}\text { 5-12 years } \\
\text { compared } \\
\text { with } \\
<5 \text { years }\end{array}$ & $\begin{array}{l}\text { Mixed } \\
\text { clinical }\end{array}$ & Not reported & $\begin{array}{l}\text { In multivariable } \\
\text { analysis, diabetes } \\
\text { associated with } \\
\text { progression of vein } \\
\text { graft stenosis/ } \\
\text { occlusion between } \\
\text { early }(<5 \text { y) and late } \\
(>5 \mathrm{y}) \text { angiography } \\
\text { study }\end{array}$ \\
\hline 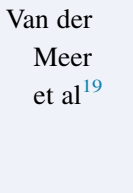 & 1994 & Multicenter & 786 & $10 \%$ & 2486 & & $1 \mathrm{y}$ & $\begin{array}{l}\text { RCT } \\
\text { (CABADAS); } \\
\text { protocol or } \\
\text { clinical if }<1 \text { y }\end{array}$ & $86 \%$ & $\begin{array}{l}12.7 \% \text { SV occlusion; } \\
\text { diabetes risk factor } \\
\text { in multivariable } \\
\text { analysis; OR, } 2.07 \\
(1.13-3.80)\end{array}$ \\
\hline $\begin{array}{c}\text { Hoogwerf } \\
\text { et } \mathrm{al}^{20}\end{array}$ & 1999 & Multicenter & 1351 & $9 \%$ & $\begin{array}{l}\text { Not } \\
\quad \text { reported }\end{array}$ & & $\begin{array}{l}\text { Baseline } \\
\text { and } \\
4 \text { years } \\
\text { from study } \\
\text { entry: } \\
\text { baseline } \\
\text { 1-11 years } \\
\text { post-CABG }\end{array}$ & $\begin{array}{l}\text { RCT } \\
\text { (post-CABG); } \\
\text { protocol }\end{array}$ & Not reported & $\begin{array}{l}\text { Progression of graft } \\
\text { disease not different } \\
\text { in adjusted model } \\
\text { (\% arterial grafting } \\
\text { not reported; time } \\
\text { since CABG not } \\
\text { factored) }\end{array}$ \\
\hline $\begin{array}{l}\text { Schwartz } \\
\text { et } \mathrm{al}^{21}\end{array}$ & 2002 & Multicenter & 568 & $19 \%$ & 2993 & $20 \%$ & $\begin{array}{c}3.9 \pm 1.8 \\
\text { years }\end{array}$ & $\begin{array}{l}\text { RCT (BARI); } \\
\text { protocol or } \\
\text { clinical }\end{array}$ & $\begin{array}{l}37 \% ; 77 \% \\
\text { and } 79 \% \\
\text { at } 1 \text { and } \\
5 \mathrm{y} \text { at } \\
\text { prespecified } \\
\text { sites }\end{array}$ & $\begin{array}{l}71 \% \text { vs } 75 \% \text { patency } \\
\text { with/without } \\
\text { diabetes }(P=.40) \\
\text { in multivariable } \\
\text { analysis diabetes } \\
\text { not associated with } \\
\text { stenosis; OR, } 0.87 \\
(0.58-1.32)\end{array}$ \\
\hline $\begin{array}{l}\text { Goldman } \\
\text { et }^{2 l^{22}}\end{array}$ & 2004 & Multicenter & 1079 & $6 \%$ & $\begin{array}{l}\text { Not } \\
\quad \text { reported }\end{array}$ & & $\begin{array}{l}1 \text { week to } \\
10 \text { years }\end{array}$ & $\begin{array}{l}\text { VA cooperative; } \\
\text { protocol or } \\
\text { clinical }\end{array}$ & $86 \%$ & $\begin{array}{l}\text { Diabetes not a } \\
\text { predictor of graft } \\
\text { patency }\end{array}$ \\
\hline $\begin{array}{l}\text { Yilmaz } \\
{\text { et } \mathrm{al}^{23}}\end{array}$ & 2005 & $\begin{array}{l}\text { Single } \\
\text { center }\end{array}$ & 314 & $19 \%$ & $\begin{array}{l}\text { Not } \\
\quad \text { reported }\end{array}$ & & $\begin{array}{l}\text { Up to } \\
5 \text { years }\end{array}$ & Clinical & $\begin{array}{l}\text { Only patients } \\
\text { with } \\
\text { angiography } \\
\text { included }\end{array}$ & $\begin{array}{l}\text { Diabetes a predictor in } \\
\text { multivariable } \\
\text { analysis; OR, } 1.36 \\
(1.01-3.44)\end{array}$ \\
\hline 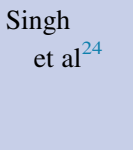 & 2008 & Multicenter & 440 & $26 \%$ & 440 & $26 \%$ & $1 \mathrm{y}$ & $\begin{array}{l}\text { RCT (RAPS); } \\
\text { protocol }\end{array}$ & $78 \%$ & $\begin{array}{l}\text { Diabetes a predictor in } \\
\text { multivariable } \\
\text { analysis; RR, } 1.45 \\
(1.03-2.05)\end{array}$ \\
\hline
\end{tabular}


TABLE 1. Continued

\begin{tabular}{|c|c|c|c|c|c|c|c|c|c|c|}
\hline Reference & Year & Site & $\begin{array}{c}\text { Patients } \\
\text { studied, } \\
\text { n }\end{array}$ & Diabetic & $\begin{array}{c}\text { SV } \\
\text { grafts, } \\
\text { n }\end{array}$ & Diabetic & $\begin{array}{l}\text { Length of } \\
\text { follow-up }\end{array}$ & $\begin{array}{c}\text { Indication } \\
\text { for } \\
\text { angiography }\end{array}$ & $\begin{array}{c}\text { Study } \\
\text { patients with } \\
\text { angiographic } \\
\text { follow-up }\end{array}$ & Finding \\
\hline $\begin{array}{l}\text { Deb } \\
\qquad{\text { et } \mathrm{al}^{15}}^{15}\end{array}$ & 2014 & Multicenter & 269 & $31 \%$ & 269 & $31 \%$ & $7.7 \pm 1.5 \mathrm{y}$ & $\begin{array}{c}\text { RCT (RAPS); } \\
\text { protocol; } 234 \\
\text { angiography } \\
\text { and } 35 \text { CTA }\end{array}$ & $75 \%$ & $\begin{array}{l}\text { SV graft patency } \\
\text { lower in diabetics } \\
(79.7 \% \text { vs } 86.2 \% \text {; } \\
P=.03) \text {; in } \\
\text { multivariable } \\
\text { analysis interaction } \\
\text { between diabetes } \\
\text { and SV graft } \\
\text { resulting in lower } \\
\text { patency }(P=.02)\end{array}$ \\
\hline $\begin{array}{l}\text { Ayan } \\
{\text { et } \mathrm{al}^{25}}^{25}\end{array}$ & 2015 & $\begin{array}{l}\text { Single } \\
\text { center }\end{array}$ & 586 & $\begin{array}{l}50 \% \\
\text { PS } \\
\text { matched }\end{array}$ & $\begin{array}{l}\text { Not } \\
\quad \text { reported }\end{array}$ & & $\begin{array}{l}\text { Up to } \\
10 \text { years }\end{array}$ & Clinical & Not reported & $\begin{array}{l}\text { In propensity-matched } \\
\text { groups (DM vs no } \\
\text { DM), SV graft } \\
\text { stenosis }(50 \% \text { vs } \\
41.8 \% ; P=.05) \\
\text { and occlusion } \\
(40.8 \% \text { vs } 32.9 \% \text {; } \\
P=.04) \text { higher in } \\
\text { diabetics }\end{array}$ \\
\hline $\begin{array}{c}\text { Koshizaka } \\
\text { et }^{26}\end{array}$ & 2015 & Multicenter & 1816 & $38 \%$ & Not reported & & $1 \mathrm{y}$ & $\begin{array}{l}\text { RCT } \\
\text { (PREVENT IV); } \\
\text { protocol for } \\
\text { first } 2400 \text { of } \\
3104 \text { patients } \\
\text { or clinical }\end{array}$ & $\begin{array}{l}76 \% \text { of } \\
\text { those } \\
\text { planned }\end{array}$ & $\begin{array}{l}\text { After adjustment no } \\
\text { difference diabetic } \\
\text { vs nondiabetic: } \\
\text { graft level: OR, } \\
1.06 \text { (0.9-1.26; } \\
P=.472) ; \text { patient } \\
\text { level: OR, } 2.08 \\
(0.88-1.31 ; \\
P=.475) \mathrm{SV} \text { grafts } \\
\text { not reported } \\
\text { separately }\end{array}$ \\
\hline $\begin{array}{l}\text { Raza } \\
\text { et }^{1}{ }^{1}\end{array}$ & 2016 & $\begin{array}{l}\text { Single } \\
\text { center }\end{array}$ & 11,519 & $12 \%$ & 20,066 & $13 \%$ & $\begin{array}{l}\text { Up to } \\
20 \text { years }\end{array}$ & Clinical & $\begin{array}{l}20 \% ; 13 \% \\
\text { of diabetic } \\
\text { patients; } \\
10 \% \text { of } \mathrm{SV} \\
\text { grafts in } \\
\text { diabetic } \\
\text { patients }\end{array}$ & $\begin{array}{l}\text { Early }(P=.90) \text { and } \\
\text { late }(P=.80) \\
\text { patency of SV } \\
\text { grafts were similar } \\
\text { in patients with and } \\
\text { without diabetes }\end{array}$ \\
\hline
\end{tabular}

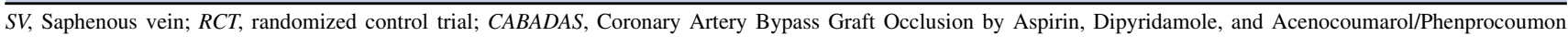
Study; $O R$, odds ratio; $C A B G$, coronary artery bypass grafting; BARI, Bypass Angioplasty Revascularization Investigation; VA, Veterans Affairs; RAPS, Radial Artery Patency Study; $R R$, risk ratio; $C T A$, computerized tomographic angiography; $P S$, propensity score; $D M$, diabetes mellitus; $P R E V E N T$, Project of Ex-Vivo Vein Graft Engineering via Transfection.

interest, the stunning conclusion of this study is that the presence of diabetes appears to have no effect on early or late patency of SV bypass grafts. Perhaps even more puzzling is the clear independent association of diabetes with mortality even after careful propensity matching to account for associated morbidity, despite an absence of difference in graft patency.

When confronted with evidence that appears to contradict theory, it is wise to re-examine the evidence as well as the theory in an effort gain greater insight. In this particular case, the rationale for pursuing the question is compelling. Current estimates suggest that nearly 30 million Americans are afflicted with diabetes, with another 86 million prediabetic patients at risk for developing type 2 diabetes. ${ }^{2}$ Increasing prevalence, driven in part by an epidemic of obesity, yield predictions that by the year 2050 between 1 in 5 and 1 in 3 adults will have the disease. ${ }^{3}$ The association of diabetes with cardiovascular disease is dramatic, threatening to reverse an entire generation of progress in reducing mortality: 
adults with diabetes are 2 to 4 times more likely to have cardiovascular disease than those without it, and at least $65 \%$ will die from their cardiovascular disease. ${ }^{4}$ Because the nature of cardiovascular disease in diabetic patients tends to be extensive and diffuse, with multivessel involvement, ${ }^{5,6}$ numerous prospective randomized controlled trials have shown the benefit of CABG versus percutaneous coronary intervention in diabetic patients with multivessel disease. ${ }^{7-10}$ It is therefore not surprising that, despite the relative decline in the volume of CABG surgery performed, the percentage of diabetic CABG patients in the Society of Thoracic Surgeons database now approaches $50 \%$. The survival benefit for $\mathrm{CABG}$ in diabetic patients relies on the ITA graft to the left anterior descending coronary artery, perhaps for reasons of improved patency as well as favorable downstream physiologic effects. ${ }^{11}$ Use of a second ITA in diabetic patients has been associated with survival benefit without increased burden of sternal infection, yet use of this approach remains rare in general practice. ${ }^{12,13}$ As highlighted by the recent reports form the ART (Arterial Revascularization Trial) trial, sternal wound infection can certainly be a risk with such an approach, although that study did not control for harvesting technique (skeletonized vs pedicle approach) ${ }^{14}$ Similarly, excellent results with the use of the radial artery have been achieved in diabetic patients, ${ }^{15}$ but expertise in the use of this artery is limited, and increasing concerns regarding long-term endothelial dysfunction using the radial approach to catheterization have become more widespread. ${ }^{16}$ Therefore, a clear understanding of SV graft patency in diabetic patients is not merely a matter of physiological interest, it is a high clinical priority.

Remarkably, despite greater than a half century of experience with CABG surgery-arguably the most studied operation in surgical history, the evidence regarding the relative SV graft patency in diabetic patients is remarkably sparse, and frequently contradictory (in some cases even from the same institution; see Table 1). ${ }^{17-26}$ The obvious tendency to perform a meta-analysis might seem appealing. However, sources of study bias according to Cochrane criteria-selection, performance, detection, attrition-are serious concerns in most of these studies. More troublesome is that the heterogeneity of these trials is beyond what even the most permissive of random effects models could reasonably be expected to pattern. Changes in patient selection with increasingly successful development of interventional options, vast differences in patient management, specifically with regard to antiplatelet and antilipid therapies as well as glycemic control, indications for and technique of imaging, definition of end points, completeness of follow-up, length of follow-up interval, analytical management of death as a competing variable, and sophistication and appropriateness of statistical methodology all vary considerably among studies. These differences no doubt, on some level, likely contribute to the ostensible contradiction in findings, although it should not be overlooked that the 2 studies with a uniform follow-up interval as well as a high rate of patient inclusion $^{15,19,24}$ showed a higher SV graft occlusion rate in diabetic patients.

Because of the relatively foggy image that emerges from the data, perhaps we should question the theory on which it is based. Vein graft disease has been well described as progressing through 3 related but somewhat distinct phases-an early thrombotic stage, an intermediate hyperplastic stage, and a late (from 1 year onward) atherosclerotic period. ${ }^{27}$ Although technical issuesendothelial injury, hypercoaguable state, anastomotic site, and construction-dominate in the early phase, there is considerable reason to believe that diabetic patients, with more diffusely diseased runoff vessels and multiple impairments in coagulation and fibrinolysis might be at greater risk for early graft occlusion. ${ }^{28}$ Similarly, endothelial dysfunction, growth factor dysregulation, and the role of advanced glycosylation end products all might be expected to exacerbate the process of smooth muscle cell migration and proliferation and extracellular matrix activation that characterize the hyperplastic phase. ${ }^{29}$ Last, the manifold mechanisms promoting the atherosclerotic process in diabetic patients - whether related to hyperglycemia, insulin dysregulation, lipid metabolism, cytokines, molecular receptors, or genetic expression profile-could most reasonably be expected to exacerbate the aggressive form of atherosclerosis that has been described in SV grafts. ${ }^{30}$ In other words, is the theory that diabetes would be associated with more severe SV graft disease reasonable? I think we can respond with a resounding yes.

So how could such an elegant analysis of such a large number of patients from such a distinguished institution result in an opposite conclusion? Could it be that diabetic patients receive greater medical attention and therefore are more closely monitored for medication adherence and symptom relief-and therefore present at an earlier stage of their SV graft disease than comparable nondiabetic patients who come to angiographic study? Perhaps. Certainly the shorter interval between surgery and angiography noted for the diabetic patients would support such a theory. Absence of more specific data regarding blood pressure control, lipid, and hemoglobin A1c levels make such a hypothesis conjectural at best. When looking instead at the wealth of useful and frankly interesting information, which the report from Raza and colleagues is able to provide, there are certain limitations that cannot be overlooked. Leaving aside the nagging details of how the end point was determined (presumably each of the 15,887 angiograms were not reviewed by a blinded core reading facility with standardized technique and 
protocol), how diabetes was defined (patient history vs medication history vs fasting glucose; type I vs type II; insulin-treated vs non-insulin-treated, etc), or how double-counting of specific lesions was avoided in patients who had repeat angiograms, there are several factors for which even the most elegant of statistical methodologies cannot fully accommodate. Aside from the 1-year substudy of patients who had routine angiography (Cleveland Clinic was one of the BARI [Bypass Angioplasty Revascularization Investigation] sites that performed 1- and 5-year planned angiography-what happened to the 5-year planned data?), all of the other studies were presumably performed for clinical indication. Of the 10,345 diabetic CABG patients for whom there was information, only 1372 were actually studied $-13.3 \%$. Of 38,753 graft observations, 27,969 recorded stenosis severe enough for study entry, leaving another $17.8 \%$ of grafts (and therefore a potentially substantial number of patients who might have had subclinical disease) out of the study. Last, a large proportion of angiograms were performed before 5 years (see the online Fig 2 in Raza et al), favoring that phase of the SV graft disease that is least likely to show the effect of diabetes on the most impactful atherosclerotic phase. The authors wisely provided a supplemental table showing considerable differences between the population studied and the population not studied. Unfortunately, because a deservedly famous quaternary referral center, the Clinic, in evaluating the patients not studied, must account for multiple uncertainties. The obvious issue, which the authors partially address with some very complex modeling, is that death is a competing variable (ie, theoretically if the diabetic patients had more severe disease they might have been more likely to die from it, creating the false impression in those remaining patients who were studied that the disease progression is similar). Moreover, many patients might have been studied, and even undergone percutaneous intervention or reoperation in outside facilities without the knowledge of the investigators. Other patients, or their physicians, might have elected for maximal medical management without clear indication of what was transpiring in their grafts. In brief, any study, regardless of how impressive the numbers or how sophisticated the analytics, which represents such a small and nonrepresentative portion of the total sample population, must be viewed with extreme caution. Finally, the relative comparability of SV graft disease at the time of presentation for angiography might simply reflect that the clinical threshold for study at the authors' institution is relatively comparable between diabetic and nondiabetic patients and therefore the extent of disease shown in those studies is relatively comparable.

Even if we were to accept the authors' conclusions at face value, the fact that mortality, even after careful adjustment for potential confounding factors, was higher in diabetic patients might raise serious question regarding the graft patency theory of prognosis. Indeed, most CABG patients presenting with recurring symptoms do have identifiable new graft disease. However, progressive disease in the native circulations, as well as impaired diabetic response to lipid and antiplatelet therapy direct molecular links between insulin resistance and cardiomyopathy and diabetic nephropathy, microvascular disease, and other end organ and infectious sequelae might well affect overall mortality, independent of SV graft disease. ${ }^{31}$

The theory is sound and the evidence is contradictory and questionable. What can we learn? Despite ostensible differences in the findings regarding vein graft disease, all available evidence indicates that arterial conduits are more resistant to graft disease than SV grafts. In fact, no study to date has shown a clinically significant greater stenosis rate of ITA grafts in diabetic patients. Mounting evidence does support a survival advantage for ITA as well as radial artery grafting for diabetic patients. ${ }^{12,13,32}$ Moreover, in the absence of multiple arterial grafting, the now-classic benefit for CABG over percutaneous intervention in diabetic patients might be ameliorated with the use of second-generation drug-eluting stents (although more long-term data are needed). ${ }^{33}$ Most studies, including that of Raza et al, that fail to find a greater extent of SV graft disease in diabetic patients, nonetheless report an increased mortality. Therefore, one might mistakenly apply the impressive data and analytics presented by Raza and colleagues to conclude that there is no particular reason to be incrementally concerned regarding the use of SV conduits in diabetic patients. However, a more thorough analysis of the available data might more likely lead one to conclude that increased use of arterial grafting is somewhat of an imperative in diabetic patients if we are to provide our patients with the maximal benefit from surgical revascularization.

\section{Conflict of Interest Statement}

Authors have nothing to disclose with regard to commercial support.

\section{References}

1. Raza S, Blackstone EH, Houghtaling PL, Rajeswaran J, Riaz H, Bakaeen FG, et al. Influence of diabetes on long-term coronary artery bypass graft patency. J Am Coll Cardiol. 2017;70:515-24.

2. American Diabetes Association. Economic burden of prediabetes up 74 percent over five years. Available at: http://www.diabetes.org/newsroom/ press-releases/2014/economic-burden-of-prediabetes-up-74-percent-over-fiveyears.html. Accessed October 3, 2017.

3. Boyle JP, Thompson TJ, Gregg EW, Barker LE, Williamson DF. Projection of the year 2050 burden of diabetes in the US adult population: dynamic modeling of incidence, mortality and prediabetes prevalence. Popul Health Metr. 2010;8:29.

4. American Heart Association. Cardiovascular disease \& diabetes. Available at: http://www.heart.org/HEARTORG/Conditions/Diabetes/WhyDiabetesMatters/ Cardiovascular-Disease-Diabetes_UCM_313865_Article.jsp\#.T07niXn16KI. Accessed October 3, 2017.

5. Norhammar A, Malberg K, Diderholm E, Lagerqvist B, Lindahl B, Rydén L, et al. Diabetes mellitus: the major risk factor in unstable coronary artery disease 
even after consideration of the extent of coronary artery disease and benefits of revascularization. J Am Coll Cardiol. 2004;43:585-91.

6. Goraya TY, Leibson CL, Palumbo PJ, Weston SA, Killian JM, Pfeifer EA, et al. Coronary atherosclerosis in diabetes mellitus: a population-based autopsy study. J Am Coll Cardiol. 2002;40:946-53.

7. BARI 2D Study Group, Frye RL, August P, Brooks MM, Hardison RM, Kelsey SF, MacGregor JM, et al. A randomized trial of therapies for type 2 diabetes and coronary artery disease. N Engl J Med. 2009;360:2503-15.

8. Farkouh ME, Domanski M, Sleeper LA, Siami FS, Dangas G, Mack M, et al. Strategies for multivessel revascularization in patients with diabetes. $N$ Engl J Med. 2012;367:2375-84.

9. Kappetein AP, Head SJ, Morice MC, Banning AP, Serruys PW, Mohr FW, et al. Treatment of complex coronary artery disease in patients with diabetes: 5-year results comparing outcomes of bypass surgery and percutaneous coronary intervention in the SYNTAX trial. Eur J Cardiothorac Surg. 2013;43:1006-13.

10. Verma S, Farkouh ME, Yanagawa B, Fitchett DH, Ahsan MR, Ruel M, et al. Comparison of coronary artery bypass surgery and percutaneous coronary intervention in patients with diabetes: a meta-analysis of randomized controlled trials. Lancet Diabetes Endocrinol. 2013;1:317-28.

11. Dimitrova KR, Hoffman DM, Geller CM, Dincheva G, Ko W, Tranbaugh RF. Arterial grafts protect the native coronary vessels from atherosclerotic disease progression. Ann Thorac Surg. 2012;94:475-81.

12. Puskas JD, Sadiq A, Vassiliades TA, Kilgo PD, Lattouf OM. Bilateral internal thoracic artery grafting is associated with significantly improved long-term survival, even among diabetic patients. Ann Thorac Surg. 2012;94:710-5; discussion 715-6.

13. Dorman MJ, Kurlansky PA, Traad EA, Galbut DL, Zucker M, Ebra G. Bilateral internal mammary artery grafting enhances survival in diabetic patients: a 30-year follow-up of propensity score-matched cohorts. Circulation. 2012;126:2935-42.

14. Taggart DP, Altman DG, Gray AM, Lees B, Gerry S, Benedetto U, et al. Randomized trial of bilateral versus single internal-thoracic-artery grafts. $N$ Engl J Med. 2016;375:2540-9.

15. Deb S, Singh SK, Moussa F, Tsubota H, Une D, Kiss A, et al. The long-term impact of diabetes on graft patency after coronary artery bypass grafting surgery: a substudy of the multicenter radial artery patency study. J Thorac Cardiovasc Surg. 2014; 148:1246-53; discussion: 1253.

16. Antonopoulos AS, Latsios G, Oikonomou E, Aznaouridis K, Papanikolaou A, Syrseloudis D, et al. Long-term endothelial dysfunction after trans-radial catheterization: a meta-analytic approach. J Card Surg. 2017;32:464-73.

17. Campeau L, Enjalbert M, Lesperance J, Bourass MG, Kwiterovich P, Wacholder S, et al. The relation of risk factors to the development of atherosclerosis in saphenous-vein bypass grafts and the progression of disease in the native circulation. N Engl J Med. 1984;311:1329-32.

18. Lytle BW, Loop FD, Cosgrove DM, Ratliff NM, Easley K, Taylor PC. Long-term (5-12 years) serial studies of internal mammary artery and saphenous vein coronary bypass grafts. J Thorac Cardiovasc Surg. 1985;89:248-58.
19. Van der Meer J, Hillege H, van Gilst W, de la Riviere AB, Dunselman PH Fidler V, et al. Coronary bypass surgery: a comparison of internal mammary artery and saphenous vein grafts after coronary artery bypass surgery: no difference in 1-year occlusion rates and clinical outcome. Circulation. 1994;90: 2367-74.

20. Hoogwerf BJ, Waness A, Cressman M, Canner J, Campeau L, Domanski M, et al. Effects of aggressive cholesterol lowering and low-dose anticoagulation on clinical and angiographic outcomes in patients with diabetes. Diabetes. 1999;48:1289-94.

21. Schwartz L, Kip KE, Frye RL, Alderman EL, Schaff HV, Detre KM. Coronary bypass graft patency in patients with diabetes in the bypass angioplasty revascularization investigation (BARI). Circulation. 2002;106:2652-8.

22. Goldman S, Zadina K, Moritz T, Ovit T, Sethi G, Copeland JG, et al. Long-term patency of saphenous vein and left internal mammary artery grafts after coronary artery bypass surgery. J Am Coll Cardiol. 2004;44:2149-56.

23. Yilmaz MB, Guray U, Guray Y, Biyikoglu SF, Tandogan I, Sasmaz H, et al. Metabolic syndrome negatively impacts early patency of saphenous vein grafts. Coron Artery Dis. 2006;17:41-4.

24. Singh SK, Desai ND, Petroff SD, Deb S, Cohen EA, Radhakrishnam S, et al. The impact of diabetic status on coronary artery bypass graft patency. Circulation. 2008;118(Suppl 1):S222-5.

25. Ayan M, Saurav A, Kabach A, Smer A, Salih M, Abuzaid A, et al. Impact of diabetes mellitus on graft patency following coronary artery bypass surgery: a propensity score analysis. J Am Coll Cardiol. 2015;66(Suppl B):B110.

26. Koshizaka M, Lopes RD, Reyes E, Gibson CM, Schulte PJ, Hafley GE, et al Long-term clinical and angiographic outcomes in patients with diabetes undergoing coronary artery bypass graft surgery: results from the project of ex-vivo vein graft Engineering via transfection IV trial. Am Heart J. 2015;169: 175-84.

27. Motwani JG, Topol EJ. Aortocoronary saphenous vein graft disease: pathogenesis, predisposition, and prevention. Circulation. 1998;97:916-31.

28. Alzahrani SH, Ajjan RA. Coagulation and fibrinolysis in diabetics. Diab Vasc Dis Res. 2010;7:260-73.

29. Aronson D, Bloomgarden Z, Rayfield E. Potential mechanisms promoting restenosis in diabetic patients. J Am Coll Cardiol. 1996;27:528-35.

30. Gleissner CA, Galkina E, Nadler JL, Ley K. Mechanisms by which diabetes increases cardiovascular disease. Drug Discov Today Dis Mech. 2007;4 131-40.

31. Bittle JA. Percutaneous coronary interventions in the diabetic patient: where do we stand? Circ Cardiovasc Interv. 2015;8:e001944.

32. Gaudino M, Crea F, Cammerton F, Massetti M. The radial artery: a forgotten conduit. Ann Thorac Surg. 2015;99:1479-85.

33. Bangalore S, Guo Y, Samadashvili Z, Blecker S, Xu J, Hannan EL. Everolimuseluting stents or bypass surgery for multivessel coronary disease. $N$ Engl J Med. 2015;372:1213-22. 